\title{
Economic and Financial Crimes Commission (EFCC) As A Strategy For Managing Nigerian External Reserves For Sustainable Development
}

\author{
Faboyede, Olusola Samuel ${ }^{1}$, Okafor, Chinonye $\mathrm{PhD}^{2}$, and \\ Onochie, Maxwell Prosper ${ }^{3}$ \\ ${ }^{1}$ (Department of Accounting, College of Development Studies, Covenant University, Canaan Land, Ota, \\ Ogun State, Nigeria). \\ ${ }^{2}$ (Department of Business Studies, College of Development Studies, Covenant University, Canaan \\ Land, Ota, Ogun State, Nigeria). \\ ${ }^{3}$ (Department of Administration and Management, College of Business and Social Sciences, Crawford \\ University, Faith City, Igbesa, Ogun State, Nigeria).
}

\begin{abstract}
Good governance allows a responsible economic and financial management of a nation's public and natural resources, for the purpose of growth and development. Nigeria's ability to make remarkable progress in curbing corruption and instituting pragmatic/workable economic and public sector reforms in the system via anti-corruption activities will give her a chance to achieve sustainable growth and development in the management of external reserves. The mechanisms of Economic and Financial Crimes Commission (EFCC), Independent and Corrupt Practices Commission (ICPC) and due process have been very instrumental in this regard. An empirical survey on the performance of EFCC shows that the agency is a very key strategy in redeeming the battered image of the Nigeria and making her external reserves management skills a successful one in spite of the fact that criticisms have trailed the agency's activities. The paper concludes that on the overall, the realization of the laudable objectives of good external reserves management will be a mirage if leadership problems of lack of integrity, transparency, corruption, and a travesty/disregard for due process, continue to subsist due to an absence of a vehicle for accountability like the EFCC.
\end{abstract}

Keywords: Development, EFCC, External reserves management, Sustainable growth.

\section{Introduction}

Nigeria's first democratic experience which began in 1960 was botched when the military struck and took over power in 1963. That marked the beginning of nearly 3 decades of military rule in Nigeria. A second democratic government held office within this period from 1979 to 1983 before another military coup toppled it. In 1999, Nigeria began its third democratic journey with President Olusegun Obasanjo at the helm of affairs. Nigerians, for about 30 years, did not have a voice in governance and decision making in their country. Throughout the period of military rule, they were mere onlookers in the affairs of their country as the military ruled with Decrees and Edicts which ousted the jurisdiction of the courts to entertain questions of the validity of their provisions.

The mid 1980s and the 1990s marked the rise of Human Rights Activists and Patriots who fought for Nigeria's return to democracy amidst torture, unlawful detention, assassinations and the rest from the military. Nigeria finally regained freedom from military rule in 1999. The new democratic government was saddled with the responsibility of reshaping and rebuilding Nigeria, which has experienced years of institutional decay and unchecked corruption. Apart from inheriting enormous infrastructural decay, the government also inherited a huge debt burden. These debts incurred by successive military regimes were not used judiciously and transparently and so projects for which the loans were obtained largely failed.

Nigeria's debt burden began in the 1970s through the 1980s when successive military governments borrowed unchecked against future oil receipts. In the late 1970s and 1980s, countries of the South, particularly African countries experienced severe savings gap and shortage of funds for investment. In the face of low interest rates, some countries including Nigeria succumbed to the temptation of resorting to external borrowing. Thanks be to God that Nigeria's debts which stood at about USD34 billion received some forgiveness. While about USD28 billion or $85 \%$ of the debt was owed to the Paris Club of 15 creditor nations, only $8 \%$ of the debt was owed to multilateral institutions such as the African Development Bank and the World Bank whilst the balance of $7 \%$ was owed to the London Club of Commercial creditors and holders of promissory Notes. Nigeria's debt was therefore a Paris Club debt. The debt stock dishearteningly grew to USD34 billion in the 1980s. Interest rates rose from between 3 and $4 \%$ which were the rates at the time of lending and peaked at $13 \%$ in 1989 making the debts of most developing countries including Nigeria's to quadruple. Indeed, whilst passing 
a resolution for repudiation of Nigeria's debts on grounds of unsustainability, members of the lower Law making body in Nigeria noted that while the entire debt stock was valued at about USD19 billion in 1985, USD37 billion was paid between 1985 and 2002 and yet about USD34 billion remained outstanding as at December, 2004. Nigeria could really be said on moral grounds claim, to have paid her debts because she had paid over USD42 billion in external debts servicing, an amount which was more than it actually borrowed. (Odu, 2005). Nigeria's creditors were unwilling to heed her request for debt relief for notable reasons such as: Nigeria's large revenue from oil; the problem of corruption in Nigeria; and Poor policy performance,

According to chief of staff to the chairman of the Economic and Financial Crimes Commission (EFCC), about \$20-trillion had been stolen from Nigeria's coffers by leaders who had access to the nation's money between 1960 and 2005. It was saddening to know that the bulk of the \$20-trillion stolen came after year 2000. As at year 2000, record showed that \$100-billion had been stolen, with an external debt of \$33-billion. This showed that the central problem facing the nation was that of governance as leaders were just looting, not caring for the people that they were expected to provide basic amenities for (Haastrup, 2006). According to Independent Advocacy Project, (2010), the absence of good governance does not allow a responsible economic and financial management of public and natural resources, for the purpose of economic growth, social development and poverty reduction.

From the aforementioned, it is evident that the history of corruption in Nigeria is strongly rooted in the over 29 years of military rule, out of 47 years of her statehood since 1960. Successive military regimes subdued the rule of law, facilitated the wanton looting of the public treasury, decapitated public institutions and free speech and instituted a secret and opaque culture in the running of government business. The result was total insecurity, poor economic management, and abuse of human rights, ethnic conflicts and capital flight. Democracy was restored in Nigeria only in May 1999, with the election of the civilian government under the leadership of President Olusegun Obasanjo.

It is against the above background of the need to prevent Nigerians from continued suffering of want and deprivation as a result of the failures and misdeeds of past leaders, realize the tenets and principles of the United Nations which are based on freedom, development and security for all, meet the Millennium Development Goals without help in spite of revenues from oil exports which when spread over her large population of 130 million people translates to no more than 53 cents a day per person, etc that necessitates this paper. This research therefore explores the instrumentality of EFCC in bailing Nigeria out of the pandemic challenges encountered by nations in the effective management of external reserves. The paper further reviews the critical assessment of the performance of EFCC, with a view to examining its impact on the society, and proffering recommendations for its maximum efficiency.

\subsection{Hypotheses}

The following null hypotheses will be tested in the course of this work.

Ho: The existence of EFCC is not a relevant component for External Reserves Management in Nigeria.

Ho: Curbing of corruption and improving Nigeria's external image are not elements for External Reserves Management.

\section{External Reserves Management in Nigeria}

External reserves represent the ultimate line of defense if the worthiness of a country is considered important for access to new credits. A respectable level of reserve serves as a notice to the watching international community that the country's economic prospects are good, thereby enhancing the confidence of international investors to bring in foreign investment. The Central Bank of Nigeria is responsible for formulating and realizing the external sector policy objectives of the country. It is to maintain an adequate level of external reserves in the form of monetary gold, reserve position at the International Monetary Fund, holdings of Special Drawing Rights (SDR) and holdings of convertible currencies of other countries to safeguard the international value of the country's legal tender currency and ensure the Country s external economic stability. The CBN has traditionally kept the external reserves as deposits with foreign banks with no known Nigerian interest. But for the first time, the CBN has appointed foreign assets managers to manage part of the country's reserves, in line with global best practice. This is to be done in partnership with 14 Nigerian commercial banks the CBN gave the green light to for management of a portion of the nation's external reserves. The objective for the appointment of external fund managers for the nation's foreign reserves was to allow for professional management, diversification of investment and to leverage on the expertise of the foreign banks to transform Nigerian banks into global financial institutions (Ogbonna, 2006).

The objectives of the management of Nigeria's external reserves are to: provide liquidity for the settlement of transactions with the rest of the world in periods of temporary imbalances in the balance with Nigerian; ensure the availability of foreign exchange for intervention in the foreign exchange market in support of the exchange rate; enhance the country s international credit worthiness; and provide cushion against or 
buffer against external shocks such as a sudden fall in the prices of exports (economic stability). The higher the domestic propensity to import, the higher the level of reserves required to sustain such level of transactions. At all times, the accepted norm is to maintain enough reserves to cover four months imports (Okigbo, n.d.). For the country to realize her potentials, succeed democratically, and prosper economically on a sustainable basis, the massive and monumental corruption going on in the land must be tamed. (Economic and Financial Crimes Commission, 2006; Obajemu, 2007)).

\subsection{Transparency and Anti-corruption Efforts in Nigeria}

One cardinal programme of the Federal administration is the fight against corruption and waste in the public service. This has been demonstrated by the establishment of two major anti-graft institutions, the Independent Corrupt Practices (And Other Related Offences) Commission (ICPC) and the Economic and Financial Crimes Commission (EFCC) in 2000 and 2003 respectively. The Government's target is zero tolerance for corruption. Thus, according to Ribadu (2006), anti-corruption strategies engaged marshalled the following policy measures: Promulgation of laws against graft - Independent Corrupt Practices And (Other Related Offences) Commission (ICPC) Act, Economic and Financial Crimes Commission (EFCC) Act, Money Laundering (Prohibition) Act 2004; Strengthening of anti-corruption and other economic crimes Institutions for effective law enforcement; Prosecution and conviction of high ranking administration officials; Tracing, seizing and confiscation of all proceeds of crime; Institution of the Due Process Mechanism in public sector procurements; Privatization of failing public institutions and creating an enabling environment for effective private-public partnerships; monthly publication of distributable revenue from the Federation Account to the different tiers of government; as well as Institution of transparencies in the oil and gas sector through the work of the Extractive Industries Transparency Initiative (NEITI).

\subsection{Economic and Financial Crimes Commission (EFCC)}

The EFCC which is today the arrow-head in the fight against corruption in Nigeria was established in 2003 as part of a national reform programme to address corruption and money laundering and in answer to the Financial Action Task Force (FATF) concerns about Nigeria's Anti-Money Laundering and Combating the Financing of Terrorism (AML/CFT) laws. EFCC is an inter-agency Commission comprising a 22-member Board drawn from all Nigerian Law Enforcement Agencies (LEAs) and regulators. The Commission is empowered to investigate, prevent and prosecute offenders who engage in

"Money laundering, embezzlement, bribery, looting and any form of corrupt practices, illegal arms deal, smuggling, human trafficking, and child labour, illegal oil bunkering, illegal mining, tax evasion, foreign exchange malpractices including counterfeiting of currency, theft of intellectual property and piracy, open market abuse, dumping of toxic wastes, and prohibited goods"

(Section 46, EFCC Establishment Act, 2004) ( cited in Ribadu, 2006)

The Commission is also responsible for identifying, tracing, freezing, confiscating, or seizing proceeds derived from terrorist activities. EFCC is also host to the Nigerian Financial Intelligence Unit (NFIU), vested with the responsibility of collecting suspicious transactions reports (STRs) from financial and designated non-financial institutions, analyzing and disseminating them to all relevant government agencies and other FIUs all over the world.

In addition to other law relating to economic and financial crimes, including the criminal and penal codes, EFCC is empowered to enforce all the pre-1999 anti-corruption and anti-money laundering laws. Punishment prescribed in the EFCC Establishment Act range from combination of payment of fine, forfeiture of assets and up to five years imprisonment depending on the nature and gravity of the offence. Conviction for terrorist financing and terrorist activities attracts life imprisonment. Indeed, the fear of EFCC is the beginning of financial transparency in Nigeria.

\subsection{EFCC Milestones So Far}

Since the establishment of EFCC in 2003, it has been involved in the investigation of cases ranging from high profile corruption cases, advanced fee fraud, money laundering, tax evasion, contract scams, identity theft, illegal oil bunkering, bribery, looting, and foreign exchange malpractices. It's been able to cleanse the banking sub-sector, sanitizing it through investigation and prosecution of Chief Executives and other officials for Money Laundering and other frauds. Bank failures which were rampant in the past have now become a thing of the past. It has led the drive to reorganize critical/key agencies and institutions of government such as the Nigeria Police, the Customs and the National Drug Law enforcement Agency (NDLEA) cleansing them of their hitherto steeped corruption. 
Further, the Commission has successfully prosecuted and secured convictions against top government functionaries, including the former chief law enforcement officer of the nation, the Inspector-General of Police (IGP). Investigation by EFCC has caused the removal from office and prosecution of a president of Senate, a governor, ministers, parliamentarians, chief executives of banks, etc. Also, there had been record convictions for '419', money laundering and terrorism. So far, 56 convictions have been recorded on corruption, money laundering, oil pipeline vandalisms and related offences. Assets well over $\$ 5$ billion have been frozen and seized from corrupt officials, their agents and cronies. EFCC further recovered and returned proceeds of crime e.g. the celebrated \$242 million case involving a Brazilian bank. Much of the amount has been recovered and returned to the bank in Brazil. The EFCC also recovered and returned the sum of $\$ 4$ million to a victim of 419 in Hong Kong and has seized and returned over $\$ 500,000$ to sundry US citizens.

Other achievements are: Setting up of the Financial Intelligence Unit, as well as taking action against money laundering and terrorist financing; Setting up machinery for monitoring activities in the Oil Industry and prevention of illegal bunkering. EFCC is vigorously addressing the nagging problem of illegal oil bunkering and pipeline vandalism in the Niger Delta Region. (Over 10 convictions on pipeline vandalism have been recorded, 25 trailers (instrumentalities of crime) seized and confiscated and accounts of beneficiaries blocked). Partnership with Microsoft against Internet Scam and Identity Theft; Capacity building for Law Enforcement and Judicial Officials (e.g. establishment of state- of-the-art Training and Research Institute in Karu, Abuja, for the training of its officials, assisting donor agencies with the training of judges handling cases of corruption, money laundering and other financial crimes); and the maintenance of excellent working relationship with major Law Enforcement Agencies all over the world (e.g. the INTERPOL, the UK Metropolitan Police, FBI, Canadian Mounted Police, the Scorpions of South Africa, etc.) (Soludo, 2007a; Soludo, 2007b).

\subsection{A Critique of EFCC Operations in Nigeria}

Serious challenges and criticisms have confronted the EFCC over its efforts on continued successful prosecution of the war on corruption in Nigeria. These include internal factors such as: relatively slow judicial system; the technological complexities in fighting economic crimes in the cyber space; lack of capacity and investigation tools such as analyses tools, financial transactions software, etc. External factors include: the availability of safe havens for corrupt Nigerian officials to keep their loot abroad; lack of cooperation from some countries etc.

EFCC has been honed to fight only the perceived enemies of Obasanjo. Ribadu has been criticized as not even handed, selective, unholistic, and a real tool in the hand of Obasanjo, allowing himself to be used to do a hatchet job (Oditta, Patrick, and Ajakaye, 2007). It has been alleged that the EFCC has done well in fighting corruption on the pages of newspapers and not in fact (Iriekpen, 2007).EFCC was accused of arm-twisting legislators to impeach their governors, flagrantly disobeying court orders, resorting to unconstitutional methods to achieve political aims and adopting the gangster approach to the fight against corruption (Ayobolu, 2006; Orilade, 2007).

There is disagreement with the choice of method of interrogations by the EFCC as many suspects in the EFCC net have complained of torture while others have insisted that the EFCC officers investigating their case did demand a bribe from them. This is an indictment on the reputation of the organ which is majorly constituted by officers who are Nigerian Policemen. The washing EFCC's administrative ineptitude on the pages of the newspaper is not good for an administration that chants rule of law and due process (Which Way Nigeria, 2006).

\section{Research Methods}

This study is based on both primary and secondary data. Primary data was obtained from respondents through the instrument of a five-likert scale questionnaire which was administered to three categories of people; the academics, the administrative personnel and students in a university setting. Covenant University was used for the administration of the questionnaires.

\subsection{Sample Size and Sampling Technique}

150 questionnaires were distributed and out of which 128 or $85.3 \%$ was retrieved back from the respondents. A simple random sampling method was used in selecting the respondents. Using simple random sample method helped us to administer the questionnaires without a predetermined specific order so as to have a fair represented of the population.

\subsection{Data Analysis Technique}

Descriptive analysis and regression analysis were used to analyze the data collected. While descriptive analysis was used to analyze the demographic variables of the respondents such as age, sex, educational background, departments and the positions of the respondents, regression analysis was used to test two 
hypotheses postulated in section of this work. Regression analysis will help us the test the relationship between the dependent and independent variables.

\subsection{Data Analysis}

The data collected was analyzed in this section using descriptive and regression analysis.

Table 1 Percentage Distribution by Sex

\begin{tabular}{|r|r|r|r|}
\hline & & Frequency & Percent \\
\hline Valid & Male & 55 & 43.0 \\
\hline & Female & 73 & 57.0 \\
\hline & Total & 128 & 100.0 \\
\hline & & & \\
\hline
\end{tabular}

Table 1 above shows the sex variable of the respondents. The table revealed that $43 \%$ of the respondents are male while $57 \%$ of them are female.

Table 2 Percentage Distribution by Age

\begin{tabular}{|r|r|r|r|}
\hline & & Frequency & Percent \\
\hline Valid & $15-20$ & 29 & 22.7 \\
\hline & $21-26$ & 47 & 36.7 \\
\hline & $27-32$ & 30 & 23.4 \\
\hline & $33-38$ & 15 & 11.7 \\
\hline & 39 -above & 7 & 5.5 \\
\hline & Total & 128 & 100.0 \\
\hline
\end{tabular}

Table 2, indicates that $22.7 \%$ of the respondents are in the age range of $15-20$, while $36.7 \%$ of them are in the range of $21-32,23.4 \%$ of them are in the age bracket of $27-32$ while $11.7 \%$ and $5.5 \%$ are within the age bracket of 33-38 and 39 and above respectively.

Table 3 Percentage Distribution by Educational background

\begin{tabular}{|r|r|r|r|}
\hline & & Frequency & Percent \\
\hline Valid & WASC & 48 & 37.5 \\
\hline & OND & 1 & .8 \\
\hline & HND/B.SC & 53 & 41.4 \\
\hline & MBA/M.SC & 25 & 19.5 \\
\hline
\end{tabular}

Table 3 shows $37.5 \%$ of respondents are WASC holders, $0.8 \%$ OND holders, $41.4 \% \mathrm{HND} / \mathrm{B}$.SC holders, and $19.5 \% \mathrm{MBA} / \mathrm{M} . \mathrm{SC}$. holders.

Table 4 Percentage Distribution by Department/Faculty

\begin{tabular}{|r|r|r|r|}
\hline & & Frequency & Percent \\
\hline Valid & CBS & 78 & 60.9 \\
\hline & CHD & 6 & 4.7 \\
\hline & CST & 44 & 34.4 \\
\hline & Total & 128 & 100.0 \\
\hline
\end{tabular}

Table 4 shows that $60.9 \%$ of respondents are from College of Business and Social Sciences, $4.7 \%$ from College of Human Development, and 34.4\% from College of Science and Technology.

Table 5 Percentage Distribution by Position held in the organization

\begin{tabular}{|r|r|r|r|}
\hline & & Frequency & Percent \\
\hline Valid & Students & 31 & 24.2 \\
\hline & Admin Officers & 22 & 17.2 \\
\hline & Lecturers & 75 & 58.6 \\
\hline & Total & 128 & 100.0 \\
\hline
\end{tabular}

Table 5 indicates that $24.2 \%$ of respondents are students, $17.2 \%$ admin staff, while $58.6 \%$ are lecturers.

Testing of the Hypotheses

Two null hypotheses were postulated in this study and this section contains the results of the regression analysis used for testing them.

Hypothesis One

Ho: The existence of EFCC is not a relevant component for External Reserves Management in Nigeria. 


\section{Data Presentation}

Model Summary

\begin{tabular}{|l|r|r|r|r|}
\hline Model & $\mathrm{R}$ & R Square & $\begin{array}{c}\text { Adjusted } \\
\text { R Square }\end{array}$ & $\begin{array}{c}\text { Std. Error of } \\
\text { the Estimate }\end{array}$ \\
\hline 1 & $.353^{\mathrm{a}}$ & .125 & .118 & .892425 \\
\hline
\end{tabular}

a. Predictors: (Constant), EFCC is a key strategy for external reserv es management in Nigeria

Table 6 Correlations between Independent and Dependent Variables

Coefficients

\begin{tabular}{|c|c|c|c|c|c|c|}
\hline \multirow{2}{*}{\multicolumn{2}{|c|}{ Model }} & \multicolumn{2}{|c|}{$\begin{array}{l}\text { Unstandardized } \\
\text { Coeff icients }\end{array}$} & \multirow{2}{*}{$\begin{array}{l}\text { Standardized } \\
\text { Coeff icients } \\
\text { Beta }\end{array}$} & \multirow[b]{2}{*}{$\mathrm{t}$} & \multirow[b]{2}{*}{ Sig. } \\
\hline & & $\mathrm{B}$ & Std. Error & & & \\
\hline \multirow[t]{2}{*}{1} & (Constant) & 2.210 & .337 & & 6.548 & .000 \\
\hline & $\begin{array}{l}\text { EFCC is a key strategy } \\
\text { for external reserves } \\
\text { management in Nigeria }\end{array}$ & .356 & .084 & .353 & 4.242 & .000 \\
\hline
\end{tabular}

a. Dependent Variable: EFCC has been able to saf eguard Nigerian treasury and external reserves against wanton looting of public and private corrupt of ficers

Result: Since P value is less than 0.05 , that is, ( $p$-value $=0.000<0.05)$, we reject the Null Hypotheses $($ Ho) and accept Alternative Hypothesis $\left(\mathrm{H}_{1}\right)$, concluding that the existence of EFCC is a relevant component for external Reserves Management in Nigeria

\section{Hypothesis Two}

Ho: Curbing of corruption and improving Nigeria's external image are not elements for External Reserves Management.

\section{Data Presentation}

Model Summary

\begin{tabular}{|l|r|r|r|r|}
\hline Model & $\mathrm{R}$ & R Square & $\begin{array}{c}\text { Adjusted } \\
\text { R Square }\end{array}$ & $\begin{array}{c}\text { Std. Error of } \\
\text { the Estimate }\end{array}$ \\
\hline 1 & $.340^{\mathrm{a}}$ & .115 & .108 & .83793 \\
\hline
\end{tabular}

a. Predictors: (Constant), EFCC actions have led to increased investors' conf idence and foreign exchange inflow into Nigeria

Table 7 Correlations between Independent and Dependent Variables

Coefficients $^{\mathrm{a}}$

\begin{tabular}{|c|c|c|c|c|c|c|}
\hline \multirow[b]{2}{*}{ Model } & & \multicolumn{2}{|c|}{$\begin{array}{l}\text { Unstandardized } \\
\text { Coeff icients }\end{array}$} & \multirow{2}{*}{$\begin{array}{c}\text { Standardized } \\
\text { Coeff icients } \\
\text { Beta }\end{array}$} & \multirow[b]{2}{*}{$\mathrm{t}$} & \multirow[b]{2}{*}{ Sig. } \\
\hline & & $\mathrm{B}$ & Std. Error & & & \\
\hline 1 & $\begin{array}{l}\text { (Constant) } \\
\text { EFCC actions have } \\
\text { led to increased } \\
\text { investors' conf idence } \\
\text { and foreign exchange } \\
\text { inflow into Nigeria }\end{array}$ & $\begin{array}{r}2.692 \\
.362\end{array}$ & .351 & .340 & 7.661 & .000 \\
\hline
\end{tabular}

a. Dependent Variable: Activ ities of EFCC have reduced corruption, improved Nigeria's image, and her external reserves

Result: Since $\mathrm{P}$ value is less than 0.05 , that is, ( $\mathrm{p}$-value $=0.000<0.05)$, we also reject the Null Hypotheses (Ho) and accept Alternative Hypothesis $\left(\mathrm{H}_{1}\right)$, concluding that curbing of corruption and improving Nigeria's image are elements for External Reserves Management.

\section{Summary of the Findings}


Even in the face of criticisms, EFCC is very appropriate in finding solution to the central problem of good leadership which has plagued Nigeria in the management of external reserves for sustainable economic development. The Commission is very instrumental in redeeming Nigeria's external image, thereby helping to grow and manage the external reserves. The resultant effects are an increased level of investors' confidence, increased inflow of foreign investments, and reduction in capital flights out of the country. The consciousness to be fair, transparent, and accountable is being driven in the hearts of managers of national external reserves. Thus, sustainable economic development is being engendered by the fight against corruption and bad image. Indeed, the relevance of the EFCC concept to external reserves management is not in doubt.

\section{Conclusion and Recommendations}

Nigeria's ability to make remarkable progress in curbing corruption and instituting pragmatic/workable economic and public sector reforms in the system through the EFCC will give her a chance to achieve sustainable growth and development in the management of external reserves. The introduced reforms which are designed to stabilize the exchange rate, reduce inflation, reform microfinance, restructure the lower denominations of our currency, re-introduce coins, as well as promote the efficiency of the payments system are all complementary to the goal of a fruitful and effective external reserves management through a sanitized and accountable governance culture. This is because the talk and efforts about a stable macroeconomic environment or sound/vibrant external reserves management system will be a sham if the leadership problems of lack of integrity and transparency, corruption, and a travesty/disregard for due process, continue to subsist. It is hereby recommended that:

- EFCC should be continuously equipped to fight the anti-corruption war via expanded capacity and investigation tools like analyses tools and transactions software.

- The judicial system reforms must be implemented to achieve speed, fairness and equity in the Nigerian polity.

- Nigeria's foreign counterpart nations should co-operate with EFCC by not being available as safe havens for keeping treasury loot on behalf of corrupt external reserves managers.

- It is paramount to ensure that EFCC is not selective, uneven-handed and unholistic in its approach.

- To be really successful, the importance of a credible integrity for EFCC officers as well as due recourse to rule of law at all times by the body cannot be over-emphasized.

\section{References}

[1] R. Odu, Nigeria's Plea For Debt Write-Off, 2005. http://paulmason.typepad.com/newsnig8t/2005/06/nigerias plea.f.html

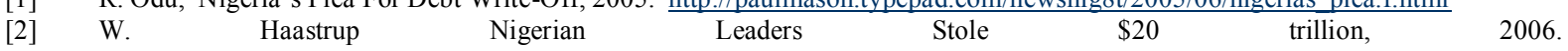

[3] $\frac{\text { http://www.africamasterweb.com/adsense/nigerialeadersstolen20trillion.html }}{\text { Independent Advocacy Project, Transparency }}+$ Accountability 2010.

[4] http://tap.resultsfordevelopment.org/grants/grantees/independent-advocacy-project-iap

[5] C. $\begin{array}{lccl}\text { http://www.sunnewsonline.com/webpages/features/money/2006/Oct/12/money-12-10-2006-002.htm } \\ \text { C. Okigbo, }\end{array}$ http://www.nigerianmuse.com/nigeriawatch/okigbo/okigbo_chapter7 pages_151 to 152.pdf

[6] Economic and Financial Crimes Commission (EFCC), Anti-Corruption Crusade, 2006. http://www.efccnigeria.org

[7] J. Obajemu, Issues On Nigeria's External Reserves. Nigerian Tribune Newspapers, Tuesday $25^{\text {th }}$ September, 2007. http://www.tribune.comng/25092007/banking.html

[8] N. Ribadu, Nigeria's Struggle with Corruption, 2006. http://ippanigeria.org/efcc.pdf

[9] C. Soludo, Nigeria's Financial System strategy 2020 Plan, 2007a. A paper presented at the Financial System Strategy 2020 International Conference in Abuja on June $18^{\text {th }}, 2007 \mathrm{http}: / /$ www.cenbank.org/fss/mon/fss2020

[10] C. Soludo, Nigeria: Strategic Agenda for the Naira, 2007b. http://www.allafrica.com/stories

[11] M. Oditta, W. Patrick, and R. Ajakaye, Workers, Lawyers, Laud Ribadu's Reappointment, 2007. http://www.efccnigeria.org/index.php

[12] D. Iriekpen, $\quad$ (2007) Nigeria: NBA Challenges Government on Corruption. 2007. http://www.allafrica.com/stories/200710230217.html

[13] J. Ayobolu, From Democracy to Babacracy: The Obasanionisation of Nigerian Politics, 2006. http://www.dawodu.com/ayobolu6.htm

[14] T. Orilade, The Plot to Mess Up Ribadu, 2007. http://www.thenewsng.com/modules/news/article

[15] Which Way Nigeria, Ruffled Feathers, 2006. http://www.whichwaynigeria.net/ruffled.feathers 